\title{
Questing for the identity of Hepatozoon in foxes
}

\author{
B Mitková1*, MA Qablan, AD Mihalca², D Modrý1,3 \\ From The 1st Conference on Neglected Vectors and Vector-Borne Diseases (EurNegVec): with Management \\ Committee and Working Group Meetings of the COST Action TD1303 \\ Cluj-Napoca, Romania. 8-11 April 2014
}

Apicomplexan parasites of genus Hepatozoon invade the blood cells of many mammalian species, being transmitted by range of arthropods. In domestic carnivores, three species of Hepatozoon were described to date: $H$. canis and $H$. americanum in dogs and $H$. felis in cats. The classification of Hepatozoon in wild carnivores is still not complete due to lack of field and experimental data as well as phylogenetic studies. The aim of this study is to carry out a survey on the prevalence and diversity of Hepatozoon sp. in red foxes Vulpes vulpes. Samples of tissues were collected from dead foxes in 11 counties of Romania; 91 samples of liver tissue were examined in total. DNA extraction was performed with commercial kit according to the manufacture's protocol. Hepatozoon sp. DNA was detected by PCR using primers amplifying 400-600 bp long part of $18 \mathrm{~S}$ rRNA gene. These primers are commonly used for diagnostic purposes in dogs and in some studies also for detection of Hepatozoon sp. in wild carnivores. PCR products were sequenced to validate positive results of reaction. DNA of parasite was confirmed in 55\% of examined samples. Recent findings classified Hepatozoon sp. in foxes and other wild canids in Europe as H. canis. However, Rhipicephalus sanguineus, the only known vector of $H$. canis in Europe, is absent in most of our sampling sites. Moreover, this tick is typical for the dogs but rare or even absent in foxes. In order to clarify the identity of the parasite, the next step of our study is to focus on amplification of longer or full segment of 18s rRNA gene to allow more accurate phylogenetic analyses and comparison with $H$. canis sequences from dogs and Hepatozoon isolates from other carnivores.

This study was supported by IGA UVPS Brno, project 115/2013/FVL.

\footnotetext{
* Correspondence: bmitkova@pobox.sk

'Department of Pathological Morphology and Parasitology, University of

Veterinary and Pharmaceutical Sciences Brno, Czech Republic
}

Full list of author information is available at the end of the article
Authors' details

${ }^{1}$ Department of Pathological Morphology and Parasitology, University of Veterinary and Pharmaceutical Sciences Brno, Czech Republic. ${ }^{2}$ Department of Parasitology and Parasitic Diseases, Faculty of Veterinary Medicine, University of Agricultural Sciences and Veterinary Medicine Cluj-Napoca, Romania. Institute of Parasitology, Biology Centre, and Faculty of Sciences, University of South Bohemia, České Budějovice (Budweis), Czech Republic.

Published: 1 April 2014

\section{doi:10.1186/1756-3305-7-S1-O23}

Cite this article as: Mitková et al:: Questing for the identity of Hepatozoon in foxes. Parasites \& Vectors 2014 7(Suppl 1):O23.
Submit your next manuscript to BioMed Central and take full advantage of:

- Convenient online submission

- Thorough peer review

- No space constraints or color figure charges

- Immediate publication on acceptance

- Inclusion in PubMed, CAS, Scopus and Google Scholar

- Research which is freely available for redistribution

Submit your manuscript at www.biomedcentral.com/submit
() Biomed Central 